\title{
Advection of freshwater phytoplankton in the St. Lawrence River estuarine turbidity maximum as revealed by sulfur-stable isotopes
}

\author{
Jean-François Lapierre, Jean-Jacques Frenette*
}

Université du Québec à Trois-Rivières, Département de Chimie-Biologie, Trois-Rivières, 3351 Boulevard des Forges, CP 500, Québec G9A 5H7, Canada

\begin{abstract}
While estuarine turbidity maxima (ETM) are commonly known for their high biological productivity, the high abundances of primary producers in these light-limited environments have long been questioned. In the St. Lawrence River ETM, we performed sampling cruises during August and October 2006 to test the hypothesis that advection of upstream algae is responsible for high phytoplankton biomass within the ETM. The ETM was situated at the freshwater end of the estuary, where salinity ranges from 0.06 to 1.10 . This abrupt peak in turbidity (up to 89.9 and 49.5 nephelometer turbidity units [NTU] during August and October, respectively) coincides with peak chlorophyll a concentrations (54.8 and $22.9 \mathrm{\mu g} \mathrm{l}^{-1}$ during August and October, respectively); surface and depth concentrations were similar in the ETM and upstream, where the water column was vertically mixed. These biomasses represented an increase of $>1$ order of magnitude compared to upstream and downstream sites, while no growth proximal factor such as light or nutrients could explain this pattern. Sulfur-stable isotopic ratios from planktonic algae in the ETM differed from those of local periphyton, but corresponded to those of attached algae grown upstream in freshwater. Phytoplankton community structures were similar throughout the salinity gradient, and the vast majority of identified algae corresponded to genera common to freshwater, ETM and downstream environments. This study provides evidence that the observed peak in phytoplankton biomass within the ETM is largely due to high inputs of phytoplankton from upstream freshwater, rather than to local growth.
\end{abstract}

KEY WORDS: Estuary $\cdot$ Turbidity $\cdot$ Light $\cdot$ Phytoplankton $\cdot$ Advection $\cdot$ Sulfur-stable isotopes

\section{INTRODUCTION}

The St. Lawrence River estuarine turbidity maximum (ETM) is found at the freshwater end of the estuary, where the confrontation of fresh and marine waters and extreme tidal currents generate an intense mixing zone, resulting in high turbidity. This critical interface for biogeochemical interactions between continental water and the sea is known for its strong biological productivity. Within this zone are found: peak concentrations of particulate organic matter (Martineau et al. 2004), chlorophyll a (chl a) (Vincent et al. 1996), zooplankton (Winkler et al. 2003) and fish larvae (Vincent et al. 1996, Vincent \& Dodson 1999), which will eventu- ally colonize downstream and upstream environments Although phytoplankton represents only $10 \%$ of the seston carbon, it is heavily grazed and constitutes the major carbon source for primary consumers, which are highly selective for these algae (Martineau et al. 2004); such selectivity has also been observed in the San Francisco estuary, where phytoplankton represents about $5 \%$ of the biomass of total organic matter (Sobczak et al. 2002).

High loss rates of phytoplankton in the ETM, and the limitations on primary productivity from reduced light penetration due to high turbidity, make the presence of peak algal biomasses in this zone difficult to explain. There have been many attempts to do so, since this 
combination of peak algal biomass and high turbidity is common in estuarine transition zones (ETZ), where salinities range from 0 to 4 . This has been observed in the United States in the San Francisco Estuary (Kimmerer et al. 2002), the Chesapeake Bay (Roman et al. 2001) and the Hudson River (Cole et al. 1992), in Belgium's Schelde Estuary (Muylaert et al. 2005) and the United Kingdom's Colne Estuary (Kocum et al. 2002), among others. To explain this apparent paradox, Wofsy (1983) suggested the possibility of an exogenous input of algae, among other hypotheses.

This is particularly relevant to the St. Lawrence ETM due to the presence of a hydrodynamic entrapment zone that increases the retention time of inorganic and organic particles because they sink into the landward bottom current and are subject to cyclonic recirculation (see Frenette et al. 1995 for a conceptual model). At Quebec City (i.e. $40 \mathrm{~km}$ upstream of the ETM), high water discharges have been reported (average discharge of $12309 \mathrm{~m}^{3} \mathrm{~s}^{-1}$; Environnement Canada, Service Météorologique), which contribute to the advection of a large phytoplankton biomass (Vincent et al. 1996) further downstream (i.e. towards the ETM). Moreover, Simons et al. (2006) reported a residence time of $15 \mathrm{~d}$ for passive particles in the ETM (such as phytoplankton cells), due to the hydrodynamic entrapment zone described above. The combination of a large advection of phytoplankton cells upstream and a relatively long particle residence time may favor the retention of phytoplankton cells in the ETM. Similar retention zones have been documented in some of the other estuaries listed above, and it has been proposed that they are responsible for the accumulation of zooplankton and phytoplankton in the ETM (Roman et al. 2001, Kimmerer et al. 2002), but no conclusive evidence has been documented yet to demonstrate this mechanism. We aimed to do so using recent technical developments allowing the separation of algae from the total seston in order to obtain a 'pure' algal signature for stoichiometry or stable isotopic ratios (Hamilton et al. 2005). It then becomes possible to determine precisely the sulfur-stable isotopic ratio of algal material, which has been shown to depend on the salinity of the environment and allowed to successfully discriminate producers in a salinity gradient (see Connolly et al. 2004).

In the present study, we: (1) provide evidence that the peak phytoplankton biomasses found in the maximum turbidity zone (MTZ) cannot be explained only by local growth and (2) demonstrate that phytoplankton found in the MTZ has a sulfur-stable isotopic ratio representative of freshwater, leading to the conclusion that most of the MTZ phytoplankton standing biomass has been advected from a freshwater, upstream environment.

\section{MATERIALS AND METHODS}

Sampling. Two $8 \mathrm{~d}$ sampling cruises were performed in summer (9 to 15 August) and fall (11 to 17 October) 2006 aboard the RV 'Lampsilis' from the Université du Québec à Trois-Rivières. The study zone was situated between Quebec City and Ile-aux-Coudres, Canada (Fig. 1), where salinity ranges from 0 to $\sim 8$. Tidal range was 6 and $3 \mathrm{~m}$ for August and October cruises, respectively; all sample collection and depth profiles were performed at an intermediate tidal state to facilitate comparison between sites. Depth was measured using an ecosounder (Raymarine). At each site, water was collected at $0.5 \mathrm{~m}$ from the surface and at $1.5 \mathrm{~m}$ above the bottom of the river using an 81 Go-Flo bottle (General Oceanics). Salinity and turbidity were measured in surface water using a multiprobe (6600 EDS-M, Yellow Spring Instruments).

Underwater light. Photosynthetically available radiation (PAR) in the water column and temperature were measured using a spectroradiometer (HyperPro, Satlantic Instruments) equipped with a temperature sensor. The instrument was weighted with a $40 \mathrm{~kg}$ mass in order to achieve verticality, and was slowly lowered into the water column; it could not be lowered $>25 \mathrm{~m}$ due to cable length limitation. Diffuse vertical attenuation light coefficients $\left(K_{\mathrm{d}}\right)$ were calculated by linear regression of a natural logarithm of PAR irradiance versus depth. The photic depth $\left(Z_{\text {eu }}\right)$, to which $1 \%$ of the subsurface irradiance penetrated, was calculated as $4.605 / K_{\mathrm{d}}$ (Kirk 1994). The percentage of the water column situated at the photic depth was then calculated as: $Z_{\mathrm{eu}} / Z_{\mathrm{m}} \times 100$, where $Z_{\mathrm{m}}$ is the mixing depth. We used the mixing depth to facilitate the comparison of algal biomass versus light availability in the surface water throughout the sampling zone. The mixing depth was defined as the upper limit of the thermocline according to the temperature profiles from the multiprobe profiler, and total depth was used when the water column was vertically mixed.

Nitrogen and phosphorus analyses. At each site, water was collected from the Go-Flo bottle for nutrient analyses. Samples for soluble reactive phosphorus (SRP) and nitrites + nitrates $\left(\mathrm{NO}_{2}+\mathrm{NO}_{3}\right)$ were prefiltrated on $45 \mathrm{~mm}$ diameter, $0.7 \mu \mathrm{m}$ pore-size GFF filters (Millipore). Concentrations of total phosphorous (TP) were obtained using the spectrophotometric determination of phosphates after digestion by persulfate. SRP was analysed using the acid molybdate technique. Nitrite and nitrate concentrations were determined as the sum of $\mathrm{NO}_{2}+\mathrm{NO}_{3}$. Nitrates were first reduced into nitrites by agitation on cadmium, then nitrite concentrations were determined by the sulphanilamide method. All nitrogen and phosphorus analyses were performed according to APHA (1998). 


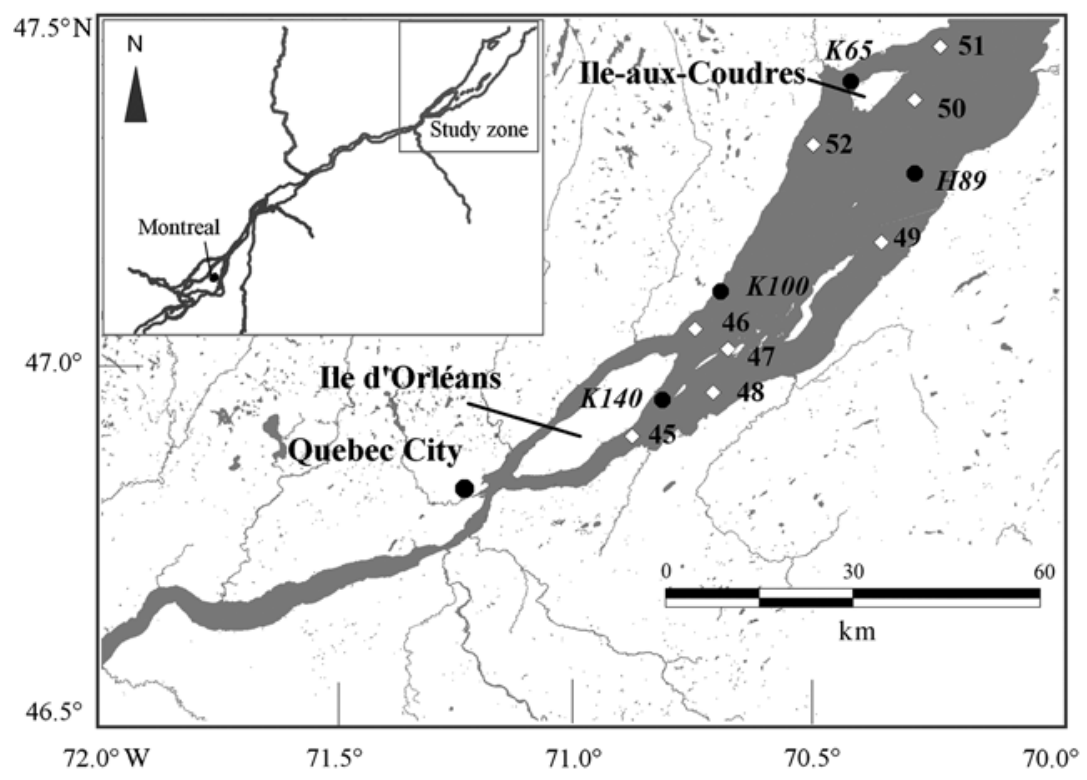

Fig. 1. Position of the sampling sites. Open diamonds with numbers: regular sampling sites; filled circles with a letter preceding a number: navigation buoys where artificial substrates were installed

Chlorophyll a. Duplicate subsamples of water from the surface and bottom were filtrated on $25 \mathrm{~mm}$ diameter, $0.7 \mu \mathrm{m}$ pore-size GFF filters (Millipore) immediately after collection, and kept frozen until analysis. Filters were sonicated in cold $90 \%$ acetone, and extraction continued for $24 \mathrm{~h}$ in the dark at $4^{\circ} \mathrm{C}$. After centrifugation, concentrations of chl a were measured on a Turner Designs fluorometer (model 10-005R) before and after acidification (Parsons et al. 1984).

Periphyton growth experiment. To obtain $\delta^{34} \mathrm{~S}$ from algae growing at a known salinity, capped 21 polyethylene containers were installed during the August cruise on 4 navigation buoys (Fig. 1), to allow colonisation by periphyton. A $5 \mathrm{~kg}$ weight was attached to the containers to obtain an incubation depth of approximately $0.25 \mathrm{~m}$. Artificial substrates were collected $58 \mathrm{~d}$ later during the October cruise. Algae were scraped off the container, then were transferred to a bottle containing filtrated water from the site. This water was shaken, then filtrated through $47 \mathrm{~mm}$ diameter, $0.7 \mu \mathrm{m}$ pore-size GFF filters (Millipore) to collect the algae. Filters were kept frozen at $-80^{\circ} \mathrm{C}$ until analysis of stable isotope signatures.

Separation of phytoplankton from the seston. Since algae in the St. Lawrence ETM represent a small proportion of the total seston (Martineau et al. 2004), we followed the methodology of Hamilton et al. (2005) to isolate phytoplankton from detrital particles to obtain a 'true' isotopic value of algal material. At each navigation buoy, 201 of water was collected in acid-washed polyethylene containers. Particulate material was concentrated using a tangential flow filtration apparatus (Millipore Pellicon) equipped with $0.45 \mu \mathrm{m}$ pore-size filters. Subsamples of the retentate were gently dispensed into $50 \mathrm{ml}$ centrifugal vials (Falcon), which were half-filled with silica gel (LUDOX TM50, Sigma-Aldrich) at a density of $1.27 \mathrm{mg} \mathrm{l}^{-1}$. They were centrifuged for $10 \mathrm{~min}$ at $1000 \mathrm{rpm}(100 \times$ $g)$, allowing heavy detrital material to precipitate.

The light fraction containing the isolated algae was collected at the silica gel-water interface and dispensed into a graduated cylinder with filtrated water from the site as described above. The algae and water were then homogenized by gentle shaking before being filtered onto $47 \mathrm{~mm}$ diameter, $0.7 \mu \mathrm{m}$ pore-sized GFF filters (Millipore) to collect isolated algae. Filters were kept frozen at $-80^{\circ} \mathrm{C}$ until analysis of stable isotope signatures. Success of the separation was verified on the analysed samples by comparing the $\mathrm{C} / \mathrm{N}$ ratios of the light fraction and the total seston, and was controlled by microscopy on separate samples using the same fractionation method (F. A. Darchambeau et al. unpubl. data). We did not directly control the purity of the light fraction from our samples by microscopy to preserve algal material for isotopic analyses.

Isotopic analyses. Stable isotope ratios for $\mathrm{S}$ were determined for total seston, isolated phytoplankton, and periphytic algae. They were expressed in delta $(\delta)$ notation (\%o) according to the general equation:

$$
\delta X=\left[\left(R_{\text {sample }} / R_{\text {standard }}\right)-1\right] \times 1000
$$

where $X$ is ${ }^{34} \mathrm{~S}$ and $R$ is ${ }^{34} \mathrm{~S} /{ }^{32} \mathrm{~S}$.

Stable isotope signatures were analysed at Iso-Analytical Limited laboratory (UK) using an elemental analysis system coupled with an isotopic ratio massspectrometer.

Phytoplankton community structure. While more detailed planktonic community composition analyses are available elsewhere for this study zone (Lovejoy et al. 1993, Frenette et al. 1995), we looked at potential major phytoplankton community shifts caused by the increasing salinity and sharp light-penetration gradients. We identified suspended algae to the genus level, and looked at the dominating groups, then at the proportion of mixotrophic algae through the sampling zone to see if mixotrophy could constitute an alternate resource acquisition mechanism that would favour 
growth in the ETM. Algal assemblages of bulk seston at the surface and bottom of Sites 45, 46, 48 and 50 for both cruises were determined in order to cover the salinity and turbidity gradients representative of the sampling region: Site 45 corresponds to the freshwater, upstream site of the ETM; Site 50 represents the estuarine site further downstream; and Sites 46 and 48 are situated in the ETM. Subsamples of site water were transferred into opaque, $125 \mathrm{ml}$, high-density polyethylene bottles (Nalgene), containing gluteraldehydeparaformaldehyde (1\% v/v final concentration). Samples were settled in Utermöhl chambers; 2 to 4 transects were counted at $400 \times$ magnification using an inverse optical microscope until at least 300 cells were observed (colonial cells were counted as 1 occurrence). Cyanophytes were counted using green epifluorescence, but were not identified to the genus level. We looked at the total richness per site (number of genera, excluding cyanophytes) and at the relative impor-
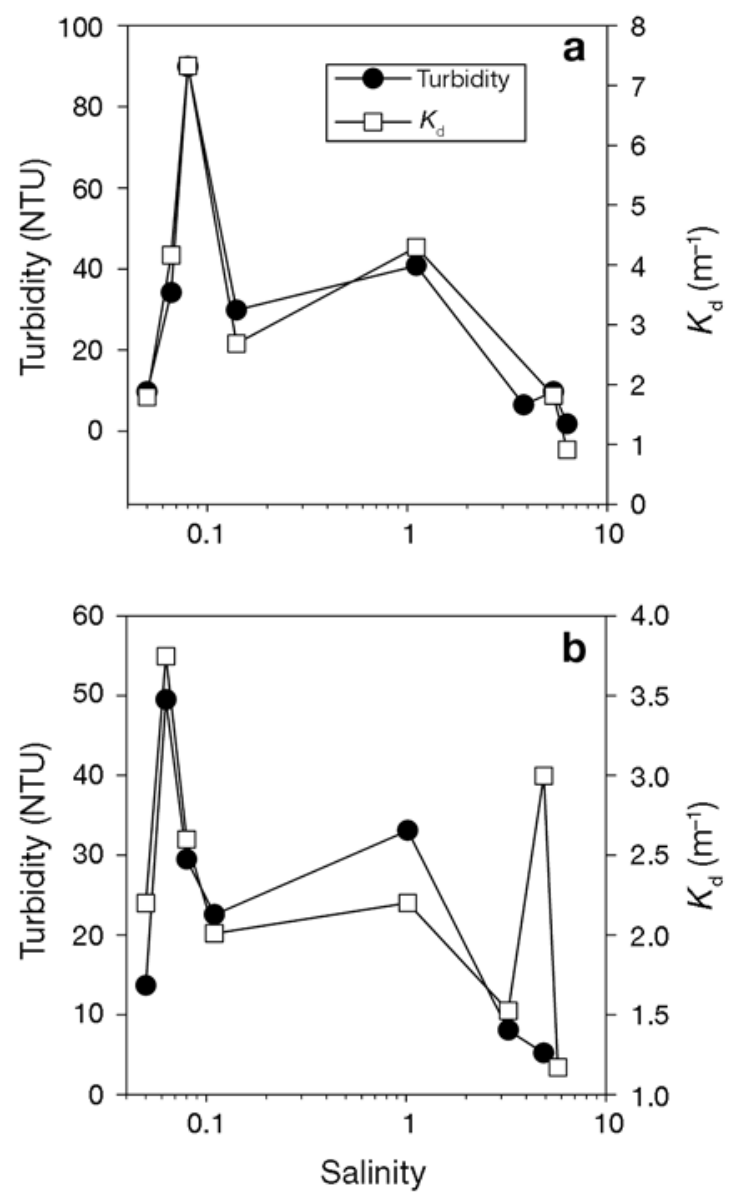

Fig. 2. Patterns of turbidity and light penetration for (a) August and (b) October cruises in relationship with salinity in the sampling zone. NTU: nephelometric turbidity units; $K_{\mathrm{d}}$ : attenuation light coefficient tance, in terms of occurrence, of each major group, i.e. chlorophytes, cryptophytes, diatoms, cyanophytes, and an 'other' group that included mixotrophic algae that do not fit into the previously identified groups. Cells were subsequently separated into a mixotrophic group, by summing cells classified as 'cryptophytes' and 'other', and into an autotrophic group, by summing cells classified as 'chlorophytes', 'diatoms' and 'cyanophytes'.

\section{RESULTS}

\section{Physical and chemical environment}

The ETM is situated at the upstream end of the ETZ, where salinities range between 0.06 and 1.1 (Fig. 2), corresponding to Sites 46 to 49 (Fig. 1). In August, turbidity peaks at 89.9 nephelometric turbidity units (NTU) and remains consistently higher within the ETM compared to upstream and downstream. High turbid-
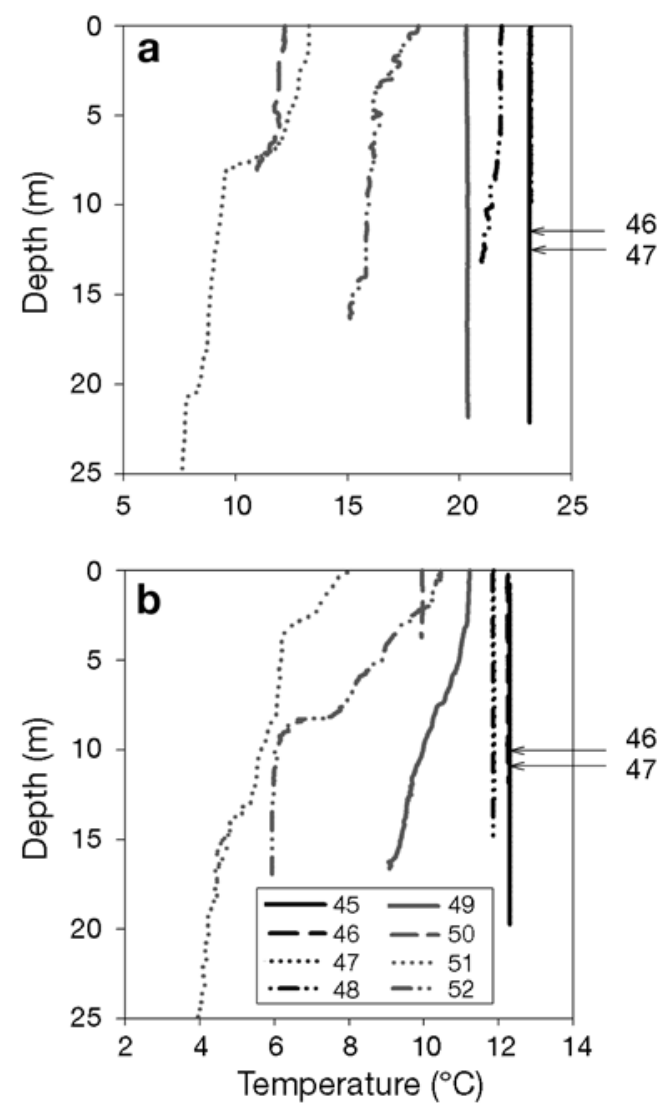

Fig. 3. Vertical temperature profiles at the sampling sites for (a) August and (b) October cruises. Note the depth of Sites 46 and 47 (right axis offset) that cannot be seen directly on the graph due to temperature overlapping with deeper Site 45 

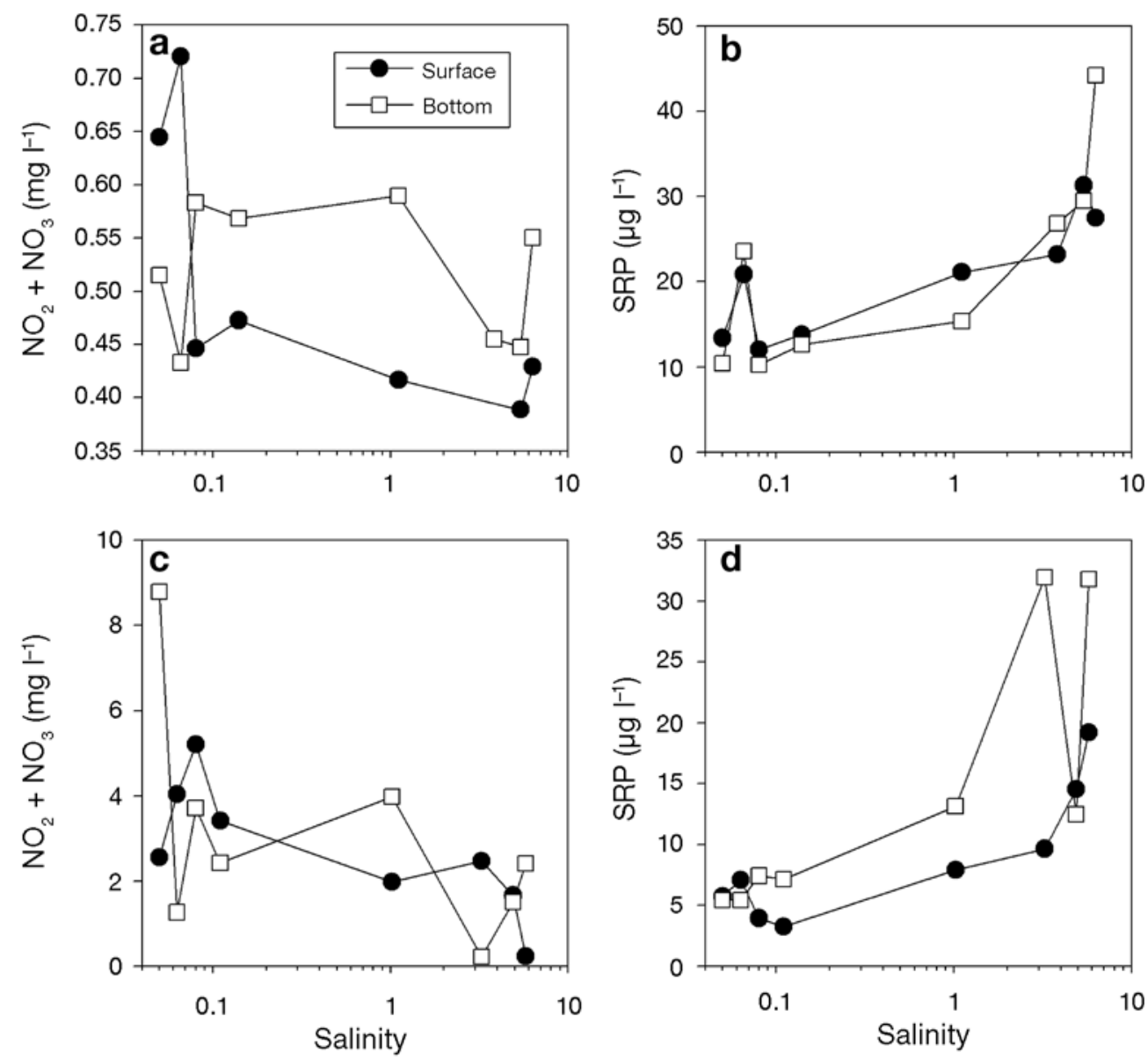

Fig. 4. Concentrations of nitrates + nitrites and soluble reactive phosphorus (SRP) for (a,b) August and (c,d) October cruises in relationship with salinity in the sampling zone

ity directly resulted in a high $K_{\mathrm{d}}$ (up to $7.3 \mathrm{~m}^{-1}$ at the turbidity peak; Fig. 2). This pattern was repeated during October, but peak values for turbidity and $K_{\mathrm{d}}$ decreased to $49.5 \mathrm{NTU}$ and $3.8 \mathrm{~m}^{-1}$, respectively (Fig. 2). The water column in the ETM is relatively shallow (Fig. 3) and becomes deeper further downstream (up to $58.7 \mathrm{~m}$ at Site 51, cannot be seen on Fig. 3 because temperature profiles stopped at $25 \mathrm{~m}$ ). The water column is well mixed at all depths for upstream and ETM sites (45 to 48 ), but stratification of the water is present starting from Sites 52 (August) and 49 (October; see Fig. 3). Temperature continually decreased in a downstream direction with growing marine influence. The slightly colder temperatures found at Site 48 compared to Sites 46 and 47 for both cruises illustrate that the mixing of marine and freshwater is not homogenous laterally; thus, the following results will be presented with regards to salinity rather than to geographic position. Nitrogen showed a general decrease with increasing salinity, while SRP increased with salinity and peaked at 31.3 and $19.2 \mathrm{\mu g} \mathrm{l}^{-1}$ in surface samples for the August and October cruises, respectively (Fig. 4).

\section{Algal biomass and light available for photosynthesis}

Concentrations of chl a increased dramatically in the ETM for surface and depth samples during both cruises, with peak concentrations in surface water of 54.8 and $22.9 \mathrm{\mu g} \mathrm{l}^{-1}$ for August and October cruises, respectively (Fig. 5). These represent, respectively, approximately 25 and 12 times the mean concentrations found at the upstream and downstream sites of the ETM in the sampling region (the means were $2.21 \mathrm{\mu g} \mathrm{l}^{-1}$ in August and $1.97 \mathrm{\mu g} \mathrm{l}^{-1}$ in October).

These peaks of algal biomass were found at high turbidity, where the euphotic zone represented $<10 \%$ of the mixing zone; the PAR irradiance penetrated most of the mixing zone downstream of the ETM, where chl a concentrations were minimal (Fig. 5). Concentrations of $\mathrm{chl}$ a were positively related to turbidity, while they 

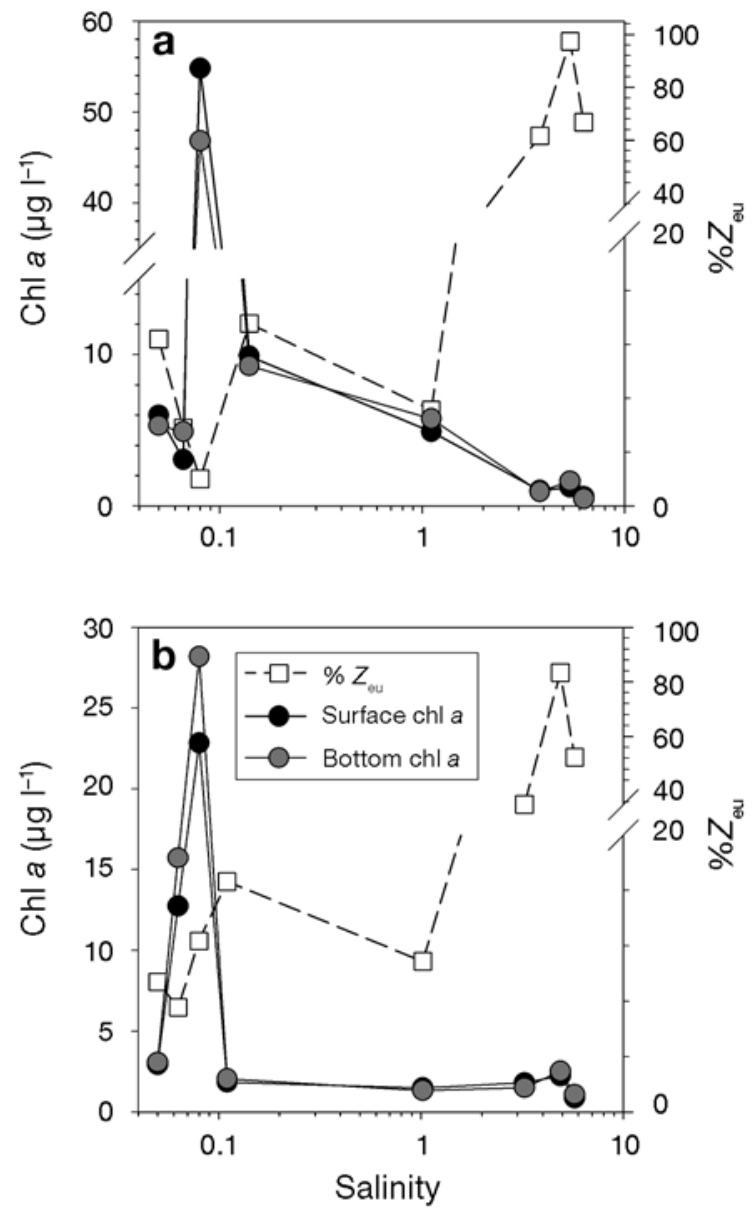

Fig. 5. Algal biomasses and percentage of the mixing depth where at least $1 \%$ of the subsurface light penetrates (photic depth, $Z_{\text {eu }}$ ) for (a) August and (b) October cruises in relationship with salinity in the sampling zone. Note breaks on the $y$-axes

were unrelated or negatively related to growthproximate factors such as light and nutrients (Fig. 6).

\section{Stable isotope signatures of algae}

Comparisons of the $\mathrm{C} / \mathrm{N}$ ratios from the isolated algae, the total seston, the Redfield ratio (Redfield 1934) and phytoplankton species in cultures (Ho et al. 2003) illustrate the success of the density fractionation technique (Table 1 ). The $\mathrm{C} / \mathrm{N}$ ratio of detrital material is halfway between the theoretical Redfield ratio for phytoplankton and total seston at a same site, suggesting the presence of a small portion of detrital material in the light fraction. Nevertheless, considering that the seston includes a certain proportion of phytoplankton and is not a true end-member of the detrital, or terrestrial, material, our results indicate that the bulk of the light fraction is actually composed of phytoplankton.
Furthermore, visual examination of separate samples before and after fractionation, using the same technique, revealed that the light fraction consisted almost exclusively of algae (F. A. Darchambeau et al. unpubl. data). We will thus use the term 'phytoplankton' to refer to the light fraction obtained from the fractionation procedure.

The $\delta^{34} \mathrm{~S}$ from periphytic algae grown on artificial substrates closely tracked the in situ salinity gradient, and ranged from 5.97 to $20.00 \%$ o (Fig. 7). On the other hand, the phytoplankton $\delta^{34} \mathrm{~S}$ throughout the sampling zone was close to the value from phytoplankton sampled upstream at the freshwater site for both cruises; this corresponded to the $\delta^{34} \mathrm{~S}$ of the periphyton growing in the freshwater portion (Fig. 7). During August, values for phytoplankton increased slightly further into the ETZ, but never came close to those of the periphyton for the corresponding site.

\section{Phytoplankton community structures}

The distribution of cell occurrences for different phytoplankton groups showed little variation when moving from freshwater toward the downstream portion of the ETM (Fig. 7, Table 2). The proportion of diatoms increased, with a concomitant decrease of cyanophytes, when moving downstream of Site 45 during both cruises. For each site, the phytoplanktonic communities were largely dominated by a small number of genera, where the 5 most abundant genera represented about $60 \%$ of the total occurrences (Table 2). Except for Thalassiosira and Skeletonema (found only in the MTZ and downstream sites), all taxa from Table 2 were found at each site and are typically representative of freshwater. There was no observed increase in the proportion of mixotrophs in the ETM during August or October (Fig. 8). Instead, we observed a general tendency for mixotrophy to decrease with the salinity gradient, except at Site 46 in October.

No distinct dominance by any particular group was observed within the ETM (Sites 46 and 48). This is well illustrated by Fig. 9, which shows the co-occurrence of

Table 1. Comparisons of mean $\mathrm{C} / \mathrm{N}$ ratios from isolated algae and total seston at the sampled sites. Literature cites correspond to expected algal $\mathrm{C} / \mathrm{N}$ ratios (see 'Results' for more information)

\begin{tabular}{|lc|}
\hline Data from: & C/N ratios \\
\hline Isolated algae & 10.9 \\
Total seston & 15.3 \\
Ho et al. (2003) & 6.6 \\
Redfield (1934) & 5.7 \\
\hline
\end{tabular}



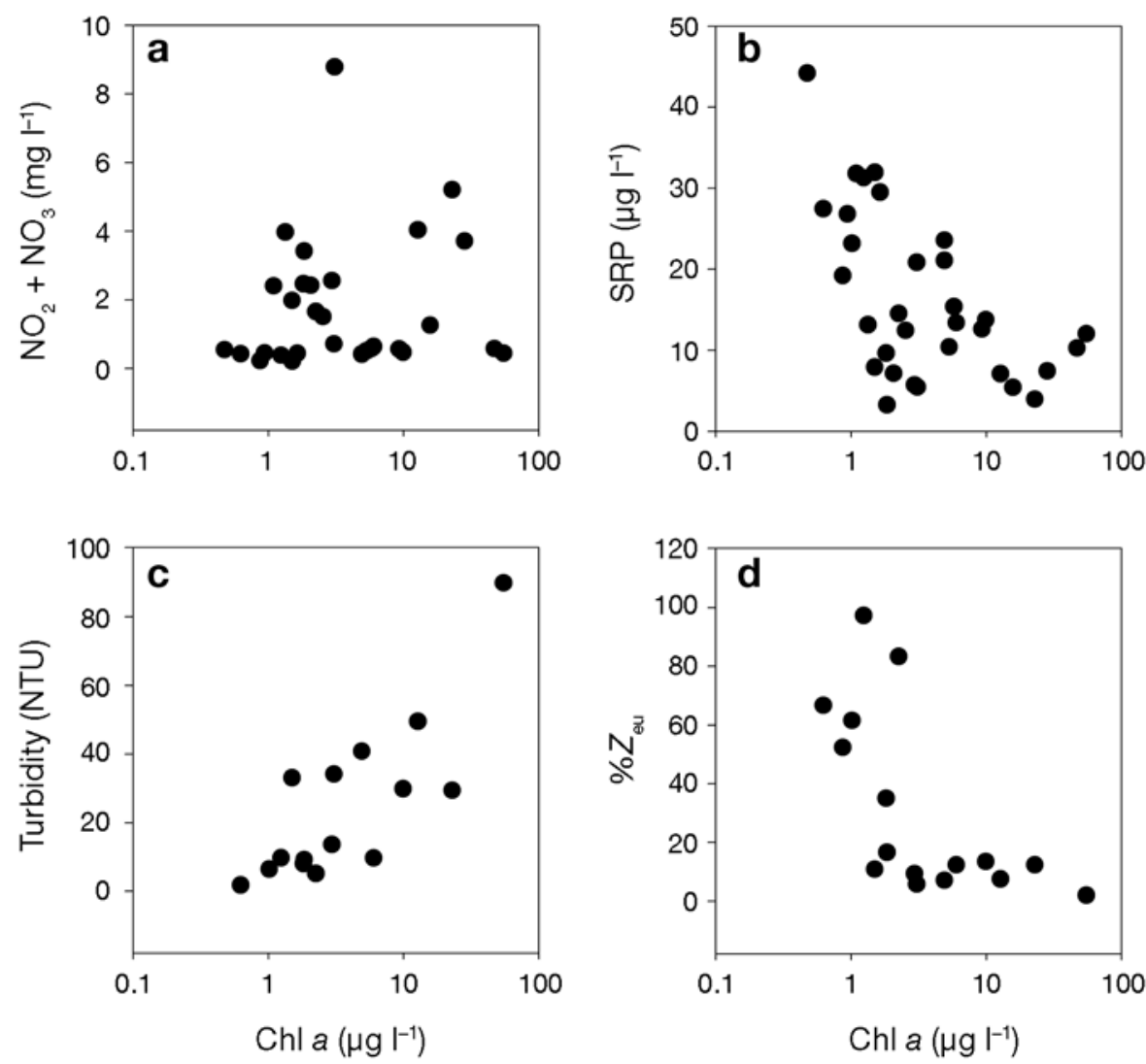

Fig. 6. Relationships between algal biomass and (a) nitrates + nitrites, (b) soluble reactive phosphorus (SRP), (c) turbidity and (d) light (photic depth, $Z_{\text {eu }}$ ). Surface and depth samples from both cruises included. NTU:nephelometric turbidity units crease in the underwater light availability in response to the prevailing high turbidity. Our results indicate that these abrupt increases could not be explained by local growth as illustrated by light or nutrient patterns in the ETM. It appears that algae achieve a long residence time in the ETM due to the hydrodynamic entrapment zone, causing an accumulation of biomass. This mechanism was previously suggested to be responsible for accumulation of detrital suspended matter and the resuspension of sediments in the ETM (Frenette et al. 1995, Martineau et al. 2004), because sinking particles reach bottom upstream currents that converge toward surface currents at the freshwater front, situated near the eastern limit of the 'Ile d'Orléans' (see Fig. 1).

Cole et al. (1992) demonstrated that local growth appeared insufficient to sustain algal biomass in the Hudson River ETM, where phytoplanktonic primary production is strongly limited by light and mixing regime. They hypothesized that high algal biomasses could only be observed at shallow sites where depth was, at most, $4 \mathrm{~m}$. Studies conducted in the San Francisco Bay and the Orinoco River genera within the different regions. Of the 58 genera identified from the August samples, 18 were common to all of the sampling regions. The upstream and ETM regions shared 31 genera, compared to 21 shared between the ETM and the downstream sites. Seven genera were observed exclusively in the ETM during the August cruise, compared to 9 during the October cruise. These represented a low percentage of the total occurrences in the ETM $(<5 \%$; Fig. 10), however, and they corresponded mostly to benthic diatoms such as Epithemia, Amphipleura and Cymatopleura. The distribution of richness was more balanced among the different zones during the October cruise compared to that in August, when a higher rate of co-occurrence was observed between the upstream and ETM regions (Fig. 10).

\section{DISCUSSION}

Concentrations of chl a increased by approximately 1 order of magnitude in both surface and bottom samples when entering the ETM, despite the sharp dedemonstrated that respiration alone can exceed photosynthesis in turbid and well-mixed environments (Alpine \& Cloern 1988, Lewis 1988). In the St. Lawrence River, Vincent et al. (1996) calculated, based

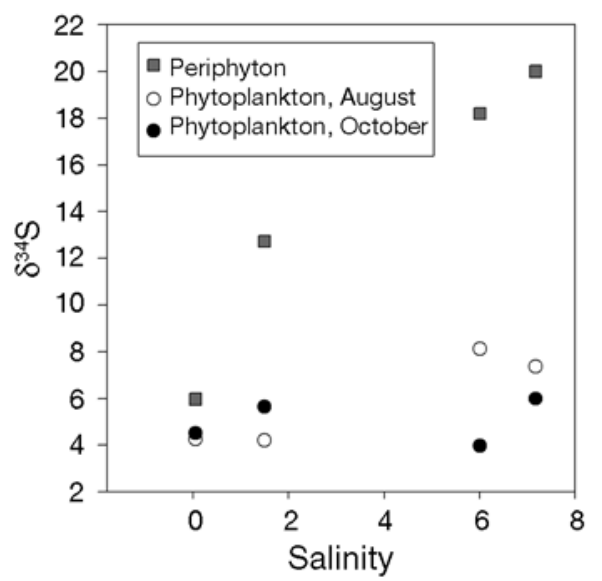

Fig. 7. Phytoplankton and periphyton S-isotopic ratios in relationship with salinity. Salinity averaged between measured values during installation and collection of the substrates at the corresponding sites 
on a mass balance model, that 20 to $30 \%$ of the phytoplankton biomass found in the ETM is advected from upstream.

We found chl a concentrations peaking at much higher values (54.8 vs. $9.9 \mu \mathrm{g} \mathrm{l}^{-1}$ ) at sites that were twice as deep, with steeper light penetration gradients, than those studied by Vincent et al. (1996). These differences are probably explained by a contrasting distribution in the sampling sites. Our observed patterns of light penetration and nutrient availability, combined with the high loss rates of phytoplankton documented by Winkler et al. (2003), agree with a high upstream contribution to chl a in the ETM. The advected phytoplankton biomass appears even higher than previously described (Vincent et al. 1996).

The isotopic results provide direct evidence that freshwater algae constitute an important fraction of phytoplankton biomass in the ETM. The relationship between salinity and periphyton S-isotopic ratios demonstrates that increasing salinity results in a direct enrichment of the heavy isotope for algae in accordance with the results of Connolly et al. (2004) based

Table 2. List of the most abundant genera at the sampling sites. Numbers correspond to the percent of occurrences for 1 genus compared to the total occurrences at this site, averaged for surface and bottom samples

\begin{tabular}{|c|c|c|c|c|c|c|c|c|}
\hline \multirow[t]{2}{*}{ Cruise } & \multicolumn{2}{|l|}{- Site 45} & \multicolumn{2}{|c|}{- Site $46-$} & \multicolumn{2}{|c|}{ Site 48} & \multicolumn{2}{|l|}{ Site 50} \\
\hline & Genus & $\%$ & Genus & $\%$ & Genus & $\%$ & Genus & $\%$ \\
\hline \multirow[t]{5}{*}{ Aug } & Ochromonas & 22.3 & Cyclotella & 32.8 & Cyclotella & 31.4 & Skeletonema & 26.8 \\
\hline & Cyclotella & 16.1 & Ochromonas & 16.5 & Navicula & 14.0 & Cyclotella & 15.2 \\
\hline & Pandorina & 7.7 & Navicula & 9.2 & Chlorella & 11.2 & Chlorella & 13.3 \\
\hline & Nitzchia & 7.2 & Chlorella & 4.3 & Nitzchia & 6.5 & Nitzchia & 5.2 \\
\hline & Navicula & 5.0 & Nitzchia & 3.8 & Thalassiosira & 5.8 & Pinnularia & 4.1 \\
\hline Total & & 58.3 & & 66.6 & & 68.9 & & 64.6 \\
\hline \multirow[t]{5}{*}{ Oct } & Navicula & 23.6 & Ochromonas & 22.4 & Cyclotella & 35.9 & Cyclotella & 26.5 \\
\hline & Ochromonas & 14.5 & Chlorella & 14.9 & Ochromonas & 12.7 & Navicula & 11.7 \\
\hline & Cocconeis & 11.1 & Navicula & 11.8 & Navicula & 6.4 & Ochromonas & 10.9 \\
\hline & Nitzchia & 9.7 & Cocconeis & 9.3 & Pinnularia & 6.1 & Skeletonema & 7.0 \\
\hline & Surirella & 4.5 & Pinnularia & 5.9 & Cocconeis & 5.5 & Nitzchia & 6.2 \\
\hline Total & & 63.4 & & 64.3 & & 66.6 & & 62.3 \\
\hline
\end{tabular}

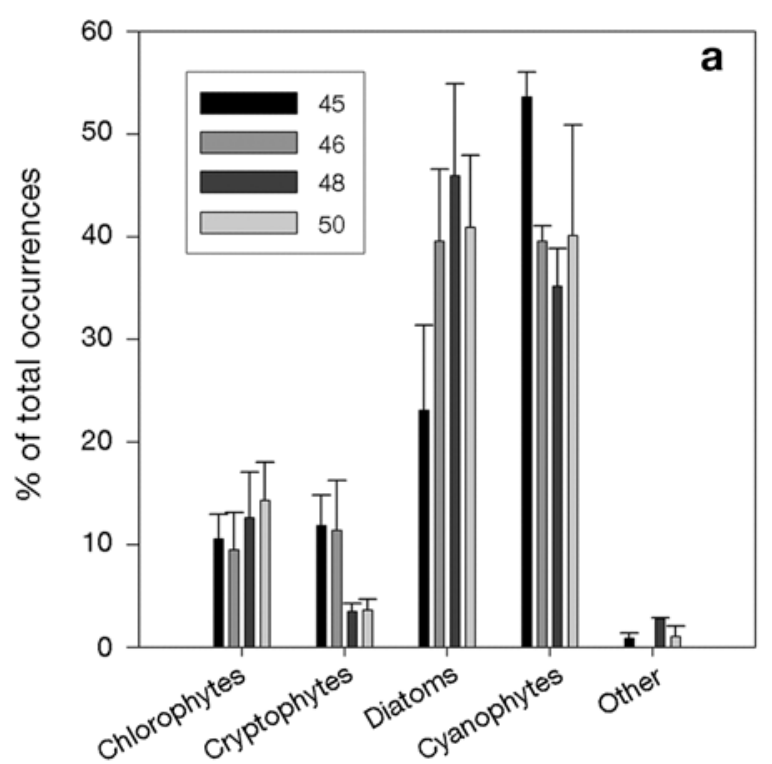

Taxonomic group

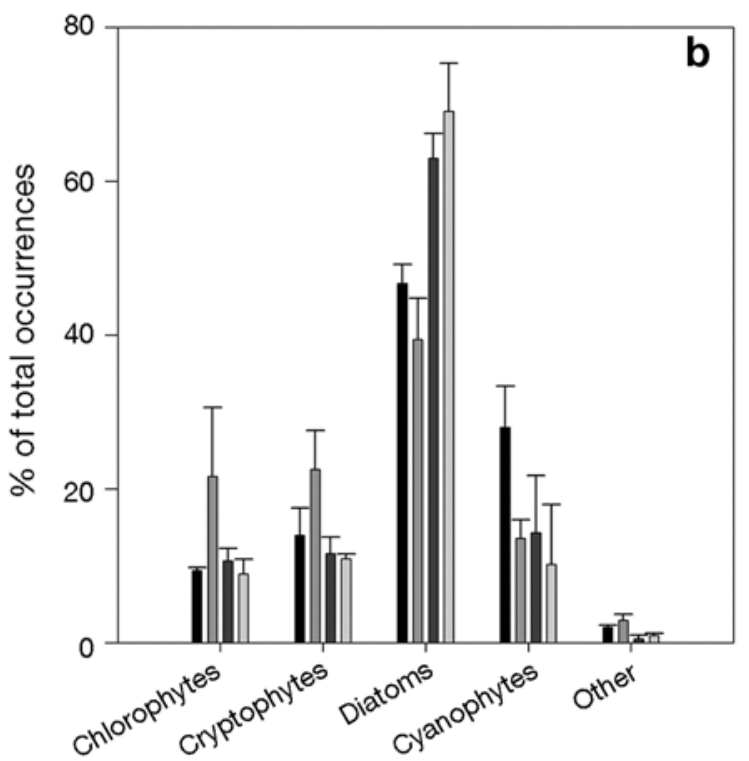

Taxonomic group

Fig. 8. Distribution, by percentage of occurrences, of the major phytoplankton taxonomic groups at Sites 45, 46, 48 and 50 (refer to Fig. 1) for (a) August and (b) October cruises. Data represent mean between surface and depth samples, $\pm 1 \mathrm{SE}$ 


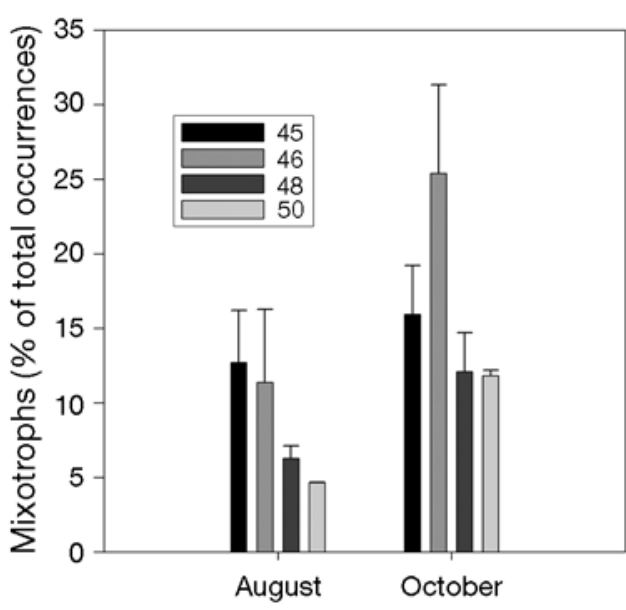

Fig. 9. Contribution of mixotrophs to the total phytoplankton community (by percentage of total occurrences) for August and October cruises at Sites 45, 46, 48 and 50 (refer to Fig. 1). Data represent mean between surface and depth samples, $+1 \mathrm{SE}$

on estuarine macrophytes. Phytoplankton S ratios from the entire sampling region, however, were close to those of the periphyton growing in freshwater, suggesting that algal communities from the ETM and further downstream spent a significant period of their growth at a freshwater site.

While several studies have shown the importance of light, nutrients, growth rate and the boundary layer effect on $\mathrm{C}$ - and $\mathrm{N}$-isotopic ratios of algae (Hecky \& Hesslein 1995, and references therein), none, to our knowledge, have underlined potential problems limiting the comparison of $\delta^{34} \mathrm{~S}$ between planktonic and periphytic algae. The results of Connolly et al. (2004) on Spartina sp. suggest that such a relationship between salinity and $\delta^{34} \mathrm{~S}$ is not exclusive to periphyton. Nonetheless, assuming a mechanism causing a salinity-related shift in $\delta^{34} \mathrm{~S}$ of phytoplankton (there is actually a $\sim 2 \%$ difference between phytoplankton and periphyton growing in freshwater), we should expect a similar increase with salinity for both groups.

Since the study sites are situated in a salinity gradient, we cannot apply a mixing model to approximate the specific proportion of algal biomass found in the ETM that originates from upstream. The absence of true end-members for the $\mathrm{C} / \mathrm{N}$ ratios also prevents the application of a mixing model to quantitatively evaluate the success of density fractionation in isolating the phytoplankton from the seston. On the higher end, the seston values include a certain portion of algae $(\sim 10 \%$ in the ETM according to Martineau et al. 2004), indicating that the real detrital, or terrestrial, component of the seston would exhibit even higher ratios. On the lower end, Redfield (1934) and Ho et al. (2003) demonstrated that eukaryotic phytoplankton acquire a $\mathrm{C} / \mathrm{N}$ ratio of about 6 . These values, however, represent an average value for a ratio that is highly variable depending on growth conditions and strategies (Arrigo 2005); resource-limited algae, for example lightlimited ones, would contain higher proportions of Crich pigments and proteins that would increase their $\mathrm{C} / \mathrm{N}$ ratios. These considerations, in addition to visual

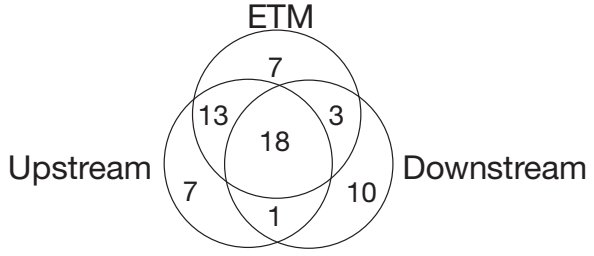

August

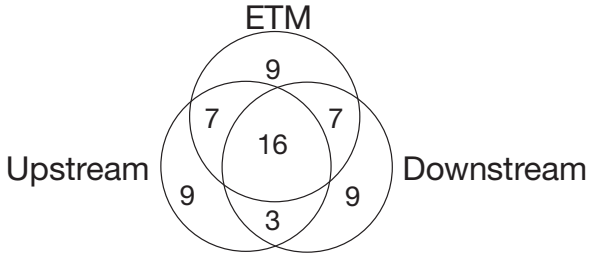

October

Fig. 10. Co-occurrence of genera between the different portions of the sampling region for August and October cruises. 'Upstream' includes Site 45, 'ETM' (estuarine turbidity maxima) includes Sites 46 and 48, and 'Downstream' includes Site 50. The numbers indicate number of genera. Surface and bottom samples are included for each site
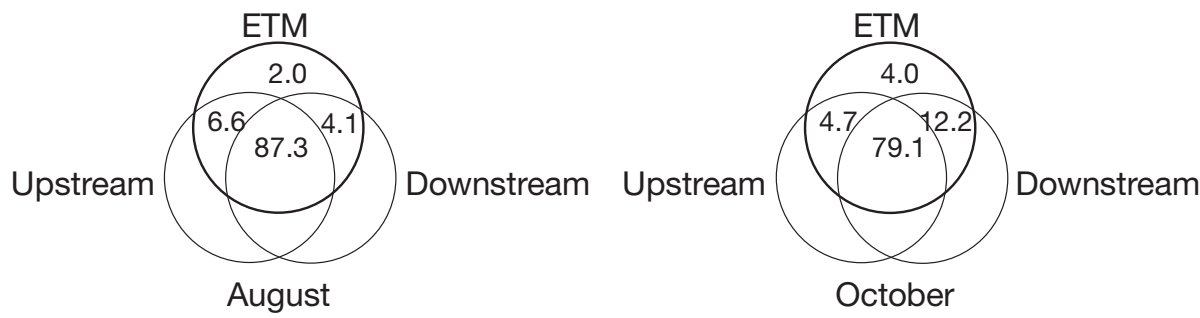

Fig. 11. Co-occurrence of genera, in percent of the total occurrences within the estuarine turbidity maxima (ETM) and among the ETM, upstream portion and downstream portion of the sampling region for August and October cruises 
examination of separated samples, suggest that the light fraction identified as isolated phytoplankton is composed mostly of algal material.

The passive accumulation of phytoplankton in the St. Lawrence River ETM requires further questioning. Simons et al. (2006) calculated a residence time for free-floating particles such as algae of approximately $15 \mathrm{~d}$ in the ETM, which is in the same range of our observed 10- to 25 -fold increase in peak chl a concentrations in the ETM compared to upstream concentrations. This indicates that the phytoplankton in the ETM achieves a relatively slow turnover rate of $\delta^{34} \mathrm{~S}$ since the values for phytoplankton throughout the sampling zone are very close to those of the freshwater periphyton. It is possible that adverse light conditions reduce algal metabolic rates and increase biomass turnover time, or that most phytoplankton found in the ETM has recently been advected, except at sites where biomasses are very high due to the particular hydrodynamics at the salinity front; Frenette et al. (1995) noted an increase in cell size within the ETM, which would promote a higher residence and survival time due to superior sinking rates and metabolic reserves in resource-limited habitats (Sandgren 1991). This would limit the acquisition of a $\delta^{34} \mathrm{~S}$ that would be representative of the ETM salinity for advected phytoplankton.

Concentrations of chl a decreased sharply just downstream of the salinity front, with a concomitant increase in phytoplankton $\delta^{34} \mathrm{~S}$, indicating a higher contribution of local algal growth. The $\delta^{34} \mathrm{~S}$ values, however, revealed that even downstream of the ETM, advection of freshwater phytoplankton makes an important contribution to the total biomass. This is consistent with the high similarity of phytoplankton community structures throughout the sampling zone; the presence of the typically marine genera Skeletonema and Thalassiosira at sites with a higher marine influence suggests that local growth becomes more important going downstream, even though these genera do not represent a high proportion of the total occurrences. The low number of samples and the limited extent of the sampling region downstream in the ETZ do not allow us to determine where local growth becomes the main source of algal biomass. The isotopic data and taxonomy results, however, suggest that freshwater algae are present at sites where salinity reaches up to 5.5 in surface waters. Roughly a third of the total genera are common to the upstream and downstream portions of the sampling region, and the vast majority of occurrences are represented by these genera.

Diatoms dominated the phytoplankton community structure during both cruises at all sites, increasing in abundance at higher salinities (from Sites 45 to 50). This agrees with previous studies in that zone (Lovejoy et al. 1993, Frenette et al. 1995, Vincent et al. 1996), which identified the ETM as a zone of diatom growth. Moreover, in the present study most of the indigenous genera observed within the ETM were resuspended benthic diatoms. Given the extensive shallows surrounding the ETM, along with tides reaching up to $6 \mathrm{~m}$ during our sampling, favourable growth conditions might indeed be met for benthic algae despite turbidity conditions, but our community structures and isotope results suggest that these do not represent an important portion of the standing planktonic biomass.

Since peaks in zooplankton and ichthyoplankton biomasses have been found at salinities slightly higher than the chl a peaks observed in the present study (Winkler et al. 2003), it is tempting to conclude that phytoplankton advected from freshwater supports the ETM's high secondary productivity. The sharp decrease in algal biomass could be explained by intense grazing by zooplankton, but further studies will be needed to document the survival and address the fate of these advected algae in the ETM, i.e. in what proportion they enter the microbial food web rather than being transferred directly to consumers. Since S-isotopic ratios of algae are related to salinity, in the St. Lawrence River ETM, it will be interesting to observe the patterns of $\delta^{34} \mathrm{~S}$ found in consumers (planktonic and benthic), to trace the contribution of freshwater algae to higher trophic levels and to determine to what extent different groups of estuarine consumers rely on local versus upstream primary production. Our results, nonetheless, suggest that the apparently high productivity in the St. Lawrence River ETM is substantially subsidized by the accumulation of algae originating from upstream freshwater input.

Acknowledgements. We are very grateful to P. Thibeault, A. Veillette, D. M'Radamy and A.-L. Larouche for help in the field and laboratory. Thanks to captain F. Harvey and his crew for the sampling aboard the 'Lampsilis'. We thank Gilbert Cabana, Julien Pommier, Hélène Glémet and 3 anonymous reviewers for helpful discussions, reviews and comments on the manuscript. This research was funded by grants from the Natural Sciences Research Council of Canada (NSERC, shiptime and discovery programs) and the Fonds Québécois de la Recherche sur la Nature et les Technologies (FQRNT) to J.-J.F., and a postgraduate NSERC and FQRNT fellowship to J.-F.L. This is a contribution from the Groupe de Recherche Interuniversitaire en Limnologie (GRIL).

\section{LITERATURE CITED}

Alpine AE, Cloern JE (1988) Phytoplankton growth rates in a light-limited environment, San Francisco Bay. Mar Ecol Prog Ser 44:167-173

American Public Health Association (1998) Standard methods for the examination of water and wastewater, 20th edn. APHA, Washington, DC 
Arrigo KR (2005) Marine microorganisms and global nutrient cycles. Nature 437:349-355

Cole JJ, Caraco NF, Peierls BL (1992) Can phytoplankton maintain a positive carbon balance in a turbid, freshwater, tidal estuary? Limnol Oceanogr 37:1608-1617

Connolly RM, Guest MA, Melville AJ, Oakes JM (2004) Sulfur stable isotopes separate producers in marine food web analyses. Oecologia 138:161-167

Frenette JJ, Vincent WF, Dodson JJ, Loveloy C (1995) Sizedependent variations in phytoplankton and protozoan community structures across the St. Lawrence River transition region. Mar Ecol Prog Ser 120:99-110

Hamilton SK, Sippel SJ, Bunn SE (2005) Separation of algae from detritus for stable isotope or ecological stoichiometry studies using density fractionation in colloidal silica. Limnol Oceanogr Methods 3:149-157

Hecky RE, Hesslein RH (1995) Contributions of benthic algae to lake food webs as revealed by stable isotope analysis. J N Am Benthol Soc 14:631-653

Ho TY, Quigg A, Finkel ZV, Milligan AJ, Wyman K, Falkowski PG, Morel FMM (2003) The elemental compostion of some marine phytoplankton. J Phycol 39:1145-1159

Kimmerer WJ, Burau JR, Bennett WA (2002) Persistence of tidally-oriented vertical migration by zooplankton in a temperate estuary. Estuaries 25:359-371

Kirk JTO (1994) Light and photosynthesis in aquatic ecosystems, 2nd edn. Cambridge University Press, Cambridge

Kocum E, Underwood GJC, Nedwell DB (2002) Simultaneous measurement of phytoplanktonic primary production, nutrient and light availability along a turbid, eutrophic UK east coast estuary (the Colne Estuary). Mar Ecol Prog Ser 231:1-12

Lewis WM (1988) Primary production in the Orinoco River. Ecology 69:679-692

Lovejoy C, Vincent WF, Frenette JJ, Dodson JJ (1993) Microbial gradients in a turbid estuary: application of a new method for protozoan community analysis. Limnol Oceanogr 38:1295-1303

Martineau C, Vincent WF, Frenette JJ, Dodson JJ (2004) Primary consumers and particulate organic matter: isotopic

Editorial responsibility: Katherine Richardson,

Copenhagen, Denmark evidence of strong selectivity in the estuarine transition zone. Limnol Oceanogr 49:1679-1686

Muylaert K, Tackx M, Vyverman W (2005) Phytoplankton growth rates in the freshwater tidal reaches of the Schelde estuary (Belgium) estimated using a simple light-limited primary production model. Hydrobiologia 540:127-140

Parsons TR, Maita Y, Lalli CM (1984) A manual of chemical and biological methods for seawater analysis. Pergamon Press, Toronto

Redfield AC (1934) On the proportions of organic derivatives in sea water and their relation to the composition of plankton. In: Daniels RJ (ed) James Johnston Memorial Volume. University Press of Liverpool, Liverpool, p 177-192

Roman MR, Holliday DV, Sanford LP (2001) Temporal and spatial patterns of zooplankton in the Chesapeake Bay turbidity maximum. Mar Ecol Prog Ser 213:215?227

Sandgren CD (1991) Growth and reproductive strategies of freshwater phytoplankton. Cambridge University Press, Cambridge

Simons RD, Monismith SG, Johnson LE, Winkler G, Saucier FJ (2006) Zooplankton retention in the estuarine transition zone of the St. Lawrence Estuary. Limnol Oceanogr 51: 2621-2631

Sobczak WV, Cloern JE, Jassby AD, Muller-Solger AB (2002) Bioavailability of organic matter in a highly disturbed estuary: the role of detrital and algal resources. Proc Natl Acad Sci USA 99:8101-8105

Vincent WF, Dodson JJ (1999) The St. Lawrence River, Canada-USA: the need for an ecosystem-level understanding of large rivers. Jpn J Limnol 60:29-50

Vincent WF, Dodson JJ, Bertrand N, Frenette JJ (1996) Photosynthetic and bacterial production gradients in a larval fish nursery: the St. Lawrence River transition zone. Mar Ecol Prog Ser 139:227-238

Winkler G, Dodson JJ, Bertrand N, Thivierge D, Vincent WF (2003) Trophic coupling across the St. Lawrence River estuarine transition zone. Mar Ecol Prog Ser 251:59-73

Wofsy SC (1983) A simple model to predict extinction coefficients and phytoplankton biomass in eutrophic waters. Limnol Oceanogr 28:1144-1155

Submitted: February 25, 2008; Accepted: August 8, 2008 Proofs received from author(s): November 14, 2008 